Boise State University

ScholarWorks

Counselor Education Faculty Publications and

Presentations

Department of Counselor Education

4-1-2017

Substance Use and Bullying Victimization Among Middle and High School Students: Is Positive School Climate a Protective Factor?

Diana M. Doumas

Boise State University

Aida Midgett

Boise State University

April D. Johnston

Boise State University 


\title{
Substance Use and Bullying Victimization Among Middle and High School Students: Is Positive School Climate a Protective Factor?
}

\author{
Diana M. Doumas* \\ Department of Counselor Education \\ Institute for the Study of Behavioral Health and Addiction \\ Boise State University \\ dianadoumas@boisestate.edu \\ Aida Midgett \\ Department of Counselor Education \\ Boise State University \\ April D. Johnston \\ Department of Counselor Education \\ Boise State University
}

Author Note: Funding for this study was provided in part by a Substance Abuse and Mental Health Service Administration Grant (SAMHSA) award number 5H79SP017028-02. The content is solely the responsibility of the authors and does not represent the official views of the National Institutes of Health or SAMHSA.

\begin{abstract}
This study examined the relationship between substance use, bullying victimization, and school climate among middle and high school students $(N=498)$. Bullying victimization predicted substance use, particularly among high schools students. Additionally, among high school students, victims with positive perceptions of school climate reported less illicit drug use.
\end{abstract}

Keywords: bullying, substance use, school climate

Underage substance use is a significant problem in the United States. According to national survey data, 66\% of students report using alcohol by their senior year (Johnston, O'Malley, Miech, Bachman, \& Schulenberg, 2015). Lifetime prevalence statistics for seniors are also high for use of marijuana (44.4\%), tobacco (34.4\%), and for illicit drug use (22.6\%) (Johnston et al., 2015). Although the highest lifetime prevalence rates of substance use are reported by seniors, substance use begins to increase in middle school, with $26.8 \%$ of eighth graders reporting alcohol use, $15.6 \%$ reporting marijuana use, $13.5 \%$ reporting tobacco use, and $10.0 \%$ reporting illicit drug use. Substance use is also associated with a variety of negative consequences for adolescents, including interpersonal, academic, legal, physical, and neurocognitive problems (Arata, Stafford \& Tims, 2003; French \& Maclean, 2006; Hanson, Median, Padula, Tapert, \& Brown, 2011; Miller, Naimi, Brewer, \& Jones, 2007; Nguyen-Louie et al., 2015; Volkow, Baler, Compton, \& Weiss, 2014). Further, youth who drink heavily and use other substances during their teen years tend to continue this pattern into college and early adulthood (D’Amico, Elickson, Collins, Martino, \& Klein, 2005; Kenney, LaBrie, \& Hummer, 2010).

The probability of adolescent substance use is likely determined by an interaction between neurobiological and environmental variables (Thatcher \& Clark, 2008). Neurobiological factors include adolescent prefrontal cortex immaturity which plays a key role in behavioral and emotional regulation (Sloboda, Glantz, \& Tarter, 2012; Steinberg, 2008). Environmental risk factors include substance availability, opportunity for use, familial factors, and peer influences (Cleveland, Feinberg, Bontempo, \& Greenberg, 2008; Sloboda et al., 2012; Thatcher \& Clark, 2008). Findings from neuroimaging studies indicate that many social brain regions continue to develop during adolescence, resulting in differences in responses to environmental risk factors such as peer influence and social evaluation (Burnett, Sebastian, Kadosh, \& Blakemore, 2010). 
This is an author-produced, peer-reviewed version of this article. The final, definitive version of this document can be found online at Journal of Addictions \& Offender Counseling, published by Wiley on behalf of the American Counseling Association. Copyright restrictions may apply. doi: 10.1002/jaoc.12025

Although peer influences are usually thought of as friends' use of substances, bullying is another type of social influence that has been understudied as a risk factor for adolescent substance use (Crothers, Kolbert, \& Hughes, 2012). National data indicate that bullying is found in elementary through high school, with approximately $25 \%$ of students reporting being bullied at school (U.S. Department of Education, 2015). Negative consequences associated with being a victim of bullying include negative emotional states (Nielsen, Tangen, Idsoe, Matthiesen, \& Mageroy, 2015; Ttofi, Farrington, Losel, \& Loeber, 2011), suicidal ideation, and suicidal attempts (Klomek, Marrocco, Kleinman, Chnonfeld, \& Gould, 2007). Victims of bullying also report decreased school attendance (Rueger \& Jenkins, 2014) and low academic achievement (Juvonen, Wang, \& Espinoza, 2011; Nakamoto \& Schwartz, 2010; Rueger \& Jenkins, 2014).

Two recent meta-analytic reviews indicate that both cross-sectional research (Valdebenito, Ttofi, \& Eisner, 2015) and longitudinal research (Ttofi, Farrington, Losel, Crago, \& Theodorakis, 2015) suggest a clear link between substance use and bully perpetration. There is, however, much less research examining the relationship between substance use and bullying victimization. Although studies consistently report positive associations between bullying victimization and substance use among high school students (Litwiller \& Brausch, 2013; Luk, Wang, \& Simons-Morton, 2010; Radliff et al., 2012; Topper, Castellanos-Ryan, Mackie, \& Conrad, 2011), the literature for middle school students is mixed with some researchers reporting a positive association (Peleg-Oren, Cardenas, Comerford, \& Galea, 2012; Sullivan, Farrell, \& Kliewer, 2006; Tharp-Taylor, Haviland, \& D’Amico, 2009) and others reporting no association (Kelly et al., 2015; Radliff, Wheaton, Robinson, \& Morris, 2012). This difference may be due to lower rates of substance use among middle school students compared to high school students. Although bullying decreases from middle school to high school (U.S. Department of Education, 2015), high school students are more likely to use substances (Radliff et al., 2012).

Differences in the relationship between bullying victimization and type of substance use have also been reported in the literature. Although the majority of research has demonstrated a positive link between victimization and substance use, some studies did not reveal a significant association for marijuana use for middle school students (Radliff et al., 2012; Sullivan et al., 2006) or high school students (Radliff et al., 2012). This may be due to lower prevalence of marijuana use as alcohol is reported as the most frequently used substance by victims of bullying, followed by tobacco and then marijuana (Radliff et al., 2012; Sullivan et al., 2006). Additionally, with the exception of one study examining inhalants among middle school students (Tharp-Taylor et al., 2009), the majority of studies conducted with this age group only investigated the association between victimization and tobacco, alcohol, and marijuana use. Similar to the middle school literature, only one high school study examined other drug use with all substances combined into a 17-item substance use scale (Litwiller \& Brausch, 2013).

Social-ecological factors related to the school setting have also been considered in the relationship between substance use and victimization. For example, Hong et al. (2014) proposed a conceptual framework that identified potential moderators of the relationship between adolescent substance use and bullying victimization including the school context. Consistent with this model, researchers have found that school climate is associated with bullying related behaviors (Eliot, Cornell, Gregory, \& Fan, 2010; Gendron, Williams, \& Guerra, 2011; Klein, Cornell, \& Konold, 2012; Low \& VanRyzin, 2014). When students perceive school climate as positive and supportive, bullying related attitudes and behaviors tend to decrease (Low \& VanRyzin, 2014). Further, when students perceive teachers and staff as supportive, students are more likely to ask for help with bullying and threats of violence (Eliot et al., 2010). On the other hand, when students perceive school climate as negative, they are more likely to engage in risk behaviors including substance use, bullying, and decreased student willingness to seek help (Klein et al., 2012).

\section{The Current Study}

Although a growing body of research supports the relationship between bullying victimization and substance use (Luk et al., 2010; Peleg-Oren, et al., 2012; Radliff et al., 2012; Sullivan et al., Tharp-Taylor et al., 2009; Topper et al., 2011), several gaps in the literature remain. First, the majority of researchers examined the relationship of bullying victimization and the use of alcohol, tobacco, and marijuana. However, data on the relationship between bullying victimization and illicit drug use are limited. Next, with the exception of one study (Radliff et al., 2012), we could find no studies examining grade level as a moderator of the relationship between bullying victimization and substance use. Similarly, although school climate is related to bullying behavior (Klein et al., 2012; Low \& VanRyzin, 2014), we could find no studies examining school climate as a moderator of the relationship between bullying victimization and substance use. 
This is an author-produced, peer-reviewed version of this article. The final, definitive version of this document can be found online at Journal of Addictions \& Offender Counseling, published by Wiley on behalf of the American Counseling Association. Copyright restrictions may apply. doi: 10.1002/jaoc.12025

The aim of the current study is to address these gaps by examining differences in the relationship between school bullying victimization and four types of substance use (e.g., alcohol, tobacco, marijuana, and illicit drugs). Additionally, we investigated grade level (middle school; high school) and school climate as a moderator of this relationship. The research questions for this study were: Is adolescent substance use predicted by bullying victimization? Are there differences for different types of substances? Does grade level moderate the relationship between substance use and bullying victimization? And, does school climate moderate the relationship between substance use and bullying victimization?

\section{Method}

\section{$\underline{\text { Participants and Procedures }}$}

Data were obtained from a school district in the capital region of a metropolitan area in the northwest that administered a Substance Use and School Climate Survey (SUSCS) to selected middle and high schools in the district. Participants were 498 (52\% male, $48 \%$ female) middle school $(n=256)$ and high school $(n=242)$ students. Participants were primarily Caucasian (74.5\%), with 11.8\% Hispanic, 6.0\% Asian, 5.2\% African-American, and 2.5\% Native American. The survey was administered by teachers and school staff using a standardized script. The survey took approximately 45 minutes to complete and was administered during a single class period. Student responses were anonymous and participation in the survey was voluntary. All study procedures were approved by the School District Research Board and the University Institutional Review Board approved analysis of data collected by the schools.

\section{$\underline{\text { Measures }}$}

Data were collected from the SUSCS which was designed for the school district by Education Northwest. The survey assesses substance use, access to substances, perceptions about substance use, school resources, school safety, and school violence. For the purpose of this study, we only used items measuring substance use, bullying victimization, and school climate.

Substance Use. The SUSCS survey included items from the Monitoring the Future survey designed to assess frequency of adolescent substance use including alcohol, tobacco, marijuana, and other substances including illicit drugs (Bachman, Johnston, \& O’Malley, 1996). Students were asked to mark "How often, if at all, do you use any of the listed types of drugs." Students rated responses on a 5-point Likert scale ranging from 1 (never) to 5 (daily). For the purpose of this study, items measuring alcohol, tobacco, marijuana, and illicit drug use were used. Alcohol use was measured by summing the three items measuring frequency of beer, wine or wine coolers, and hard liquor $(\alpha=$ .90). Tobacco use and marijuana use were each measured by one item. Illicit drug use was measured by summing four items measuring opiate, cocaine, methamphetamine, and depressant use $(\alpha=.85)$.

Bullying Victimization. The SUSCS includes five items designed to assess frequency of victimization. Students were asked "Have any of the following happened to you at school during the past 30 days?" Students rated responses on a force choice with anchors 0 (no) and 1 (yes). Example items include "I was pushed around by someone who was just being mean," "I was afraid of being beat up on the way to or from school," and "I was called names or put down by other students." Items were summed for a total bullying victimization score $(\alpha=.70)$.

School Climate. The SUSCS includes 10 items designed to assess issues related to school safety. Students rated responses on a force choice with anchors 0 (no) and 1 (yes). Example items include "I feel safe at this school," "I feel comfortable telling teachers or administrators about potential fights, arguments, or weapons at school," "School rules are fairly and consistently enforced for all students," and "Teachers show respect to students." One item was removed to improve the internal consistency of the scale to $>.70$. Items were then summed for a total school climate score ( $\alpha$ $=.77)$.

\section{Results}

Analyses were conducted using SPSS version 21. Outcome variables were examined for skew and kurtosis. The distribution for illicit drugs substantially deviated from the normal distribution ( $>3$ skew and $>9$ kurtosis) so a logarithmic transformation was used to normalize the distribution (Tabachnick \& Fidell, 2007). Means and standard deviations for substance use, victimization, and school climate are presented in Table 1. Bivariate correlations among 
predictor and dependent variables were calculated prior to conducting the main regression analyses (see Table 2). Although several of the correlations were significant at $p<.01$, the variance inflation factor (VIF) ranged between 1.1 -1.9 , with corresponding tolerance levels ranging from $.25-.90$. The VIF is below the rule of thumb of VIF $<10$ (Erford, 2015; Norman \& Streiner, 2008), suggesting acceptable levels of multicollinearity among the predictor variables.

\section{Outcome Analyses}

Our aims were to examine the relationship between substance use and victimization and to test whether the relationship between substance use and victimization is moderated by grade level and school climate. We were also interested if these relationships would be different for different types of substances. To test these aims, four hierarchical regression analyses were conducted, with interaction effects used to test for differences in grade level and school climate. Main effects (victimization, grade level, and school climate) were entered on Step 1, two-way (victimization x level, victimization x climate) and three-way (victimization x level x climate) interaction effects were entered on Step 2, and all predictor variables were mean centered to reduce problems of multicolinearity introduced into equations containing interaction terms (Aiken \& West, 1991). Simple slopes were used to examine the direction and degree of significant interactions (Aiken \& West, 1991). All analyses were conducted at $p<.05$. Power calculations indicated the current sample size should yield power of $\geq 0.95$ to detect a medium effect size for the model $\left(R^{2}=.09\right)$ and a small effect size for the $R^{2}$ change $\left(R^{2}=.01\right)$ and semi-partial correlation coefficients $\left(\mathrm{r}_{\mathrm{p}}=.10\right)$. Table 3 presents results from the regression models.

\section{$\underline{\text { Alcohol }}$}

The full regression equation was significant for alcohol, $R^{2}=.18, F(6,439)=16.9, p<.001$. Examination of the adjusted $R^{2}$ indicates victimization, grade level, and school climate accounted for $18 \%$ of the variance in alcohol use. This is a medium to large effect size. As seen in on Step 2, results showed that victimization was a significant predictor of alcohol use, $(p<.05)$. As hypothesized, higher levels of alcohol use were associated with higher levels of victimization. None of the interaction effects were significant.

\section{$\underline{\text { Tobacco }}$}

The full regression equation was significant for tobacco, $R^{2}=.11, F(6,439)=10.27, p<.001$. Examination of the adjusted $R^{2}$ indicates victimization, grade level, and school climate accounted for $11 \%$ of the variance in tobacco use. As seen in on Step 2, results showed that victimization was a significant predictor of tobacco use, $(p<.01)$. As hypothesized, higher levels of tobacco use were associated with higher levels of victimization. Further, the significant victimization $\mathrm{x}$ grade interaction term $(p<.001)$ indicates the relationship between victimization and tobacco use was moderated by grade level. To examine the nature of the interactions, tests of simple slopes were graphed and interpreted using Aiken and West's (1991) procedures. Figure 1 presents the significant two-way interaction between victimization $x$ grade. Examination of the slopes in Figure 1 indicates that among high school students, victims of bullying reported higher levels of tobacco use than non-victims.

\section{Marijuana}

The full regression equation was significant for marijuana, $R^{2}=.16, F(6,439)=15.39, p<.001$. Examination of the adjusted $R^{2}$ indicates victimization, grade level, and school climate accounted for $16 \%$ of the variance in marijuana use. As seen in on Step 2, results showed that victimization was a significant predictor of marijuana use $(p<.001)$. As hypothesized, higher levels of marijuana were associated with higher levels of victimization. Further, the significant victimization $\mathrm{x}$ grade interaction term $(p<.05)$ indicates the relationship between victimization and marijuana use was moderated by grade level. Examination of the slopes in Figure 1 indicates that among high school students, victims of bullying reported higher levels of marijuana use than non-victims.

Illicit Drugs

The full regression equation was significant for illicit drugs, $R^{2}=.16, F(6,439)=15.21, p<.001$. Examination of the adjusted $R^{2}$ indicates victimization, grade level, and school climate accounted for $16 \%$ of the variance in illicit drug use. As seen in on Step 2, results showed that victimization was a significant predictor of illicit drug use $(p<.001)$. As hypothesized, higher levels of illicit drug use were associated with higher levels of victimization. Further, the 
This is an author-produced, peer-reviewed version of this article. The final, definitive version of this document can be found online at Journal of Addictions \& Offender Counseling, published by Wiley on behalf of the American Counseling Association. Copyright restrictions may apply. doi: 10.1002/jaoc.12025

significant victimization $\mathrm{x}$ grade $\mathrm{x}$ climate interaction term, $(p<.05)$ indicates the relationship between victimization and illicit drug use was moderated by grade level and school climate. Examination of the slopes in Figure 2 indicates that among high school students reporting bullying victimization, those with negative perceptions of school climate reported higher levels of illicit drug use than those with positive perceptions of school climate.

\section{Discussion}

The present study investigated the relationship between substance use and bullying victimization. This study also tested the moderating effect of grade level and school climate on the relationship between victimization and substance use. Overall, our findings demonstrated significant associations between victimization and substance use. Victimization predicted alcohol use for both middle and high school students. In contrast, for tobacco, marijuana, and illicit drug use, grade level moderated the relationship. Specifically, victimization predicted substance use among high schools students only. Additionally, for illicit drug use, school climate moderated the relationship between bullying victimization and drug use for high school students. Findings suggest that the victimization is a risk factor for substance use, particularly for high school students, and that the impact of victimization on illicit drug use may be buffered by a safe and supportive school climate.

Results of this study are consistent with previous research indicating bullying victimization is associated with substance use (Luk et al., 2010; Peleg-Oren, et al., 2012; Radliff et al., 2012; Sullivan et al., 2006; Tharp-Taylor et al., 2009; Topper et al., 2011). Although the literature with middle school students is mixed, our findings are consistent with studies demonstrating a positive association between victimization and use of alcohol among middle school students (Peleg-Oren et al., 2012; Sullivan et al., 2006; Tharp-Taylor et al., 2009). Consistent with other studies, results of this study revealed no significant association between victimization and tobacco use (Kelly et al., 2015; Radliff et al., 2012) or marijuana use (Kelly et al., 2015; Radliff et al., 2012; Sullivan et al., 2006). In contrast, for high school students, findings revealed a significant association between bullying victimization and substance use for alcohol, tobacco, marijuana, and illicit drug use. These results add to the literature indicating bullying victimization in high school is associated with higher rates of alcohol and tobacco use (Luk et al., 2010; Radliff et al., 2012), marijuana use (Luk et al., 2010), and substance use including illicit drug use (Litwiller \& Brausch, 2013).

One explanation for the differences in the association between substance use and bullying victimization for middle and high school students may be the relative prevalence rates of substance use between these age groups. Because alcohol use has the highest prevalence rates of all substances in middle school (Johnston et al., 2015), it is not surprising that we found a relationship between victimization and alcohol use for both middle school and high school students. For tobacco, marijuana, and illicit drug use, it is possible that the lack of findings for middle school students is reflective of the low prevalence rates among middle school students. Because being bullied is associated with negative emotional states (Nielsen et al., 2015; Ttofi et al., 2011), students may turn to substances as a way to cope. Using substances to "self-medicate" may be limited to alcohol use until they enter into their high school years when the use of other substances becomes more prevalent.

Finally, among high school students, victims with positive perceptions of school climate reported less illicit drug use than those with less positive perceptions. To our knowledge, this is the first study to examine school climate as a moderator of the relationship between substance use and bullying victimization. However, this finding is consistent with literature indicating a positive school climate is associated with a decrease in bullying related attitudes and behaviors (Low \& VanRyzin, 2014) and a higher likelihood for students to ask for help when threatened with bullying (Eliot et al., 2010). It is possible that students who experience bullying victimization and perceive the school environment as supportive and safe are less likely to turn to substances to cope with the stress of being a victim of bullying. We did, however, find this buffering effect of school climate for illicit drug use only, suggesting that school climate may be protective of students moving from alcohol, tobacco, and marijuana to more dangerous drugs such as opiates and methamphetamines.

\section{Limitations and Directions for Future Research}

Although this study adds to the literature examining the relationship between substance use and bullying victimization, there are limitations. First, the primarily Caucasian composition of the sample limits the generalizability of the results. Therefore, the authors recommend future research with more diverse samples. Second, the use of a cross-sectional design limits the ability to test for directionality of these relationships or make causal statements about these variables. 
This is an author-produced, peer-reviewed version of this article. The final, definitive version of this document can be found online at Journal of Addictions \& Offender Counseling, published by Wiley on behalf of the American Counseling Association. Copyright restrictions may apply. doi: 10.1002/jaoc.12025

Future research using a longitudinal design would extend this study by allowing the investigation of the temporal understanding of these relationships. Although it seems intuitive to assume that victimization precedes substance use, it is also possible that students who use substances become targets of bullying. A third limitation concerns the measurement of victimization and school climate used in this study. Because the data was obtained from the school district, the authors created scales from available items to measure these variables. Although the alphas for these scales were adequate, future research using psychometrically validated scales of victimization and school climate should be conducted to replicate these findings. Finally, information in this in study was obtained through self-report which may lead to response bias. Self-reported alcohol use is common practice in studies examining alcohol use among adolescents and the reliability and validity of self-reported use in this age group have been demonstrated (Flisher, Evans, Muller, \& Lombard, 2004; Lintonen, Ahlstrom, \& Metso, 2004). For bullying victimization, however, other types of data including reports from parents, teachers, and peers and observational data may be preferable (Swearer, Espelage, Vaillancourt, \& Hyme, 2010). Anonymous data collection, however, may minimize the problem of social desirability.

The findings also need to be interpreted in light of the magnitude of the effect sizes. The $R^{2}$ for the full models ranged from explaining $11 \%$ to $18 \%$ of the variance in substance abuse. These effect sizes are medium to large range and support the importance of victimization, grade level, and school climate as predictors of substance use. Examination of the semi-partial correlations for significant predictors, however, indicates that many of the effect sizes were small. Given the multitude of factors that contribute to adolescent substance use, even small effect sizes are meaningful. Additionally, small effect sizes are commonly found in the adolescent substance abuse literature (Carney \& Myers, 2012).

\section{$\underline{\text { Counseling Implications }}$}

Results of this study provide directions for prevention and intervention efforts. The co-occurrence of substance use and bullying suggests that programs targeting reducing substance use should include efforts to reduce bullying. Findings suggest that with the exception of alcohol, the relationship between substance use and bullying victimization is more prevalent in high school than middle school. Bullying, however, peaks in middle school, suggesting both middle schools and high schools are appropriate settings for school-based interventions targeting bullying behavior.

One approach for combating bullying is for schools to implement comprehensive, school-wide intervention programs. Many of these programs target risk and protective factors, viewing youth behavior from a social-ecological perspective, shaped by contextual systems such as the school setting (Hong et al., 2014). These program are effective in reducing bullying behavior (Garandeau, Poskiparta, \& Salmivalli, 2014; Menard \& Grotpeter, 2014), as well as improving school climate (Brown, Low, Smith, \& Haggerty, 2011; Menard \& Grotpeter, 2014). Findings from this study suggest impacting school climate may be particularly important at the high school level due to its buffering effects between victimization and illicit drug use.

Bully-Proofing (Garrity, Jens, Porter, Sager \& Short-Camilli, 2004a, 2004b, 2004c) is an example of a comprehensive, school-wide intervention designed to reduce school bullying. Key components of the program include: 1) increasing all school stakeholders' awareness of bullying, 2) training school personnel to work with victims of bullying to increase protective factors and skills to defend themselves, 3) working with bullies to help change their behavior, and 4) shifting school climate by equipping student bystanders with strategies to intervene on behalf of victims. Researchers have found that Bully-Proofing reduces rates of bullying victimization and perpetration compared to a control group and students in schools implementing the program report higher perceptions of school safety (Menard \& Grotpeter, 2014). Bully-Proofing, however, can be difficult to implement because it requires training all stakeholders (i.e., administration, school staff, teachers, students, family members, and community members), a minimum of 15 hours of teacher preparation, and 270 days of program implementation for students and teachers (Menard \& Grotpeter, 2014).

Because some schools do not have the resources to implement comprehensive, school-wide programs, brief interventions can also be considered. For example, the STAC program (Midgett, Doumas, Sears, Lunquist, \& Hausheer, 2015) is a brief, bystander program adapted from the bystander component of Bully-Proofing (Garrity, et al., 2004c). The acronym STAC stands for "stealing the show," "turning it over," "accompany others," and "coaching compassion." The STAC program was developed to train students who witness bullying to intervene using these strategies. Counselor education students work with school counselors on program implementation that includes a 90- 
This is an author-produced, peer-reviewed version of this article. The final, definitive version of this document can be found online at Journal of Addictions \& Offender Counseling, published by Wiley on behalf of the American Counseling Association. Copyright restrictions may apply. doi: 10.1002/jaoc.12025

minute student training conducted at the school, followed by brief check-in meetings. Researchers have found preliminary evidence indicating the STAC program is effective at teaching students to identify different types of bullying, the STAC intervention strategies, and increasing general confidence intervening in bullying situations (Midgett et al., 2015; Midgett \& Doumas, in press).

In addition to providing specific interventions to change the school climate and reduce the prevalence of bullying, school counselors can also work individually with students who may be victims of bullying to provide coping skills training. Research indicates victims of bullying may develop a self-medicating style, using substances to cope with the negative emotional states associated with victimization (Topper, Casellanos-Ryab, Mackie, \& Conrad, 2011). Thus, school counselors can provide coping skills training targeting the regulation of negative affect to students who are bullied. Research indicates both Cognitive Behavioral Therapy (CBT) (Arnberg \& Öst, 2014; Hoffmann, Asnaani, Vonk, Sawyer, \& Fang, 2012) and Dialectical Behavioral Therapy (DBT) (Cook \& Gorraiz, 2016; MacPherson, Cheavens, \& Fristad, 2013) are effective in helping adolescents manage negative emotional states and problematic behavior. School counselors can use CBT to teach students to cope with difficult events by reframing distorted or negative thoughts, thereby reducing negative emotional states. School counselors can also use DBT to teach students emotional regulation skills to decrease risky behavior, including substance use, when faced with the negative affect associated with victimization.

Research also supports school-based CBT interventions for youth anxiety and depression (Mychailyszyn, Brodman, Read, \& Kendall, 2012). The authors suggest that rather than providing short-term interventions, placing coping skills training within the curriculum may be preferable. Specifically, school counselors could lead the effort to integrate teaching coping skills into the curriculum, creating a sustainable, effective, developmentally appropriate approach to providing these strategies to students. These coping skills could then be used when students are faced with difficult issues and the associated distress as an alternative to substance use. Equipping students with coping strategies can lead to healthier choices and better outcomes for students who are victims of bullying.

\section{Conclusion}

The aim of this study was to investigate the relationship between substance use, bullying victimization, and school climate among middle school and high school students. Findings indicated that victimization is related to alcohol use for both middle school and high school students, whereas the relationship between tobacco, marijuana, and illicit drug use and victimization was found among high school students only. School climate also moderated the relationship between victimization and illicit drug use, suggesting positive school climate can act as a buffer for victimized students. Results indicate it is important to provide early intervention programs to decrease bullying as being bullied is associated with substance use both in middle school and high school. Consistent with the social-ecological perspective, comprehensive programs that improve school climate may also be beneficial for high schools students, particularly in the prevention of illicit drug use among victims of bullying. Finally, we suggest school counselors provide coping skills training such as CBT and DBT to equip students with positive coping strategies they can use as an alternative to substance use as a way to manage negative emotional states associated with victimization.

\section{References}

Aiken, L. S. \& West, S. G. (1991). Multiple Regression: Testing and Interpreting Interactions. Thousand Oaks, CA: Sage Publications, Inc.

Albert, D., \& Steinberg, L. (2011). Judgment and decision making in adolescence. Journal of Research on Adolescence, 21, 211-224. doi:10.1111/j.1532-7795.2010.00724.x

Arata, C. M., Stafford, J., \& Tims, M. S. (2003). High school drinking and its consequences. Adolescence, 38, 567579.

Arnberg, A., \& Öst, L. (2014). CBT for children with depressive symptoms: A meta-analysis. Cognitive Behaviour Therapy, 43, 275-288. doi:10.1080/16506073.2014.947316

Bachman, J. G., Johnston, L. D., \& O'Malley, P. M. (1996). The Monitoring the Future project after twenty-two years: Design and procedures (Monitoring the Future Occasional Paper No. 38.) Ann Arbor, MI: Institute for Social Research, 89 pp.

Bray, J. H., Adams, G. J., Getz, J. G., \& Baer, P. E. (2001). Developmental, family, and ethnic influences on adolescent alcohol usage: A growth curve approach. Journal of Family Psychology, 15, 301-314. doi:10.1037/0893-3200.15.2.301 
This is an author-produced, peer-reviewed version of this article. The final, definitive version of this document can be found online at Journal of Addictions \& Offender Counseling, published by Wiley on behalf of the American Counseling Association. Copyright restrictions may apply. doi: 10.1002/jaoc.12025

Brown, C. E., Low, S., Smith, B. H., \& Haggerty, K. P. (2011). Outcomes from a school-randomized control trial of Steps to Respect: A bullying prevention program. School Psychology Review, 40, 423-443.

Burnett, S., Sebastian, C., Kadosh, K. C., \& Blakemore, S. (2010). The social brain in adolescence: Evidence from functional magnetic resonance imaging and behavioural studies. Neuroscience and Biobehavioral Reviews, 35, 1654-1664. doi:10.1016/j.neubiorev.2010.10.011

Carney, T., \& Myers, B. (2012). Effectiveness of early interventions for substance-using adolescents: Findings from a systematic review and meta-analysis. Substance Abuse Treatment, Prevention, and Policy, 7, 1-15. doi:10.1186/1747-597X-7-25

Cleveland, M. J., Feinberg, M. E., Bontempo, D. E., \& Greenberg, M. T. (2008). The role of risk and protective factors in substance use across adolescence. Journal of Adolescent Health, 43, 157-164. doi:10.1016/j.jadohealth.2008.01.015

Cook, N. E., \& Gorraiz, M. (2016). Dialectical behavior therapy for nonsuicidal self-injury and depression among adolescents: preliminary meta-analytic evidence. Child and Adolescent Mental Health, 21, 81-89. doi:10.1111/camh.12112

Crothers, L. M., Kolbert, J. B., \& Hughes, T. L. (2012). Beyond the brain: the role of bullying in adolescent substance abuse. Journal of Addiction Research and Therapy, 3, 1-2. doi:10.4172/2155-6105.1000e112

D’Amico, E. J., Elickson, P. L., Collings, R. L., Martino, S. K., \& Klein, D. J. (2005). Processes linking adolescent problems to substance-abuse problems in late young adulthood. Journal of Studies on Alcohol, 66, 766-775. doi:http://dx.doi.org/10.15288/jsa.2005.66.766

D’Amico, E. J., \& Fromme, K. (2000). Implementation of the risks-skills training program: A brief intervention targeting adolescent participation in risk behaviors. Cognitive and Behavioral Practice, 7, 101-117. doi:10.1016/S1077-7229(00)80011-5

Eliot, M., Cornell, D., Gregory, A., \& Fan, X. (2010). Supportive school climate and student willingness to seek help for bullying and threats of violence. Journal of School Psychology, 48, 533-553. doi:10.1016/j.jsp.2010.07.001

Erford, B. T. (2015). Research and Evaluation in Counseling. Stamford, CT: Cengage Learning.

Flisher, A. J., Evans, J., Muller, M., \& Lombard, C. (2004). Brief report: Test-retest reliability of self-reported adolescent risk behaviour. Journal of Adolescence, 27, 207-212. doi:10.1016/j.adolescence.2001.10.001

French, M. T., \& Maclean, J. C. (2006). Underage alcohol use, delinquency, and criminal activity. Health Economics, 15, 1261-1281. doi:10.1002/hec.1126

Garandeau, C. F., Poskiparta, E., \& Salmivalli, C. (2014). Tackling acute cases of school bullying in the KiVa antibullying program: A comparison of two approaches. Journal of Abnormal Child Psychology, 42, 981-989. doi:10.1007/s10802-014-9861-1

Garrity, C., Jens, K., Porter, W., Sager, N., \& Short-Camilli, C. (2004a). Bully-proofing your school: Administrator's guide to staff development in elementary schools (3rd ed.). Longmont, CO: Sopris West.

Garrity, C., Jens, K., Porter, W., Sager, N., \& Short-Camilli, C. (2004b). Bully-proofing your school: Teacher's manual and lesson plans for elementary schools (3rd ed.). Longmont, CO: Sopris West.

Garrity, C., Jens, K., Porter, W., Sager, N., \& Short-Camilli, C. (2004c). Bully-proofing your school: Working with victims and bullies in elementary schools (3rd ed.). Longmont, CO: Sopris West.

Gendron, B. P., Williams, K. R., \& Guerra, N. G. (2011). An analysis of bullying among students within schools: Estimating the effects of individual normative beliefs, self-esteem, and school climate. Journal of School Violence, 10, 150-164. Retrieved from http://dx.doi.org/10.1080/15388220.2010.539166

Hanson, K. L., Medina, K. L., Padula, C. B., Tapert, S. F., \& Brown, S. A. (2011). Impact of adolescent alcohol and drug use on neuropsychological functioning in young adulthood: 10-year outcomes. Journal of Child \& Adolescent Substance Abuse, 20, 135-154. doi:10.1080/1067828X.2011.555272

Hofmann, S. G., Asnaani, A., Vonk, I. J. J., Sawyer, A. T., Fang, A. (2012). The efficacy of Cognitive Behavioral Therapy: A review of meta-analyses. Cognitive Therapy and Research, 36, 427-440. doi:10.1007/s10608012-9476-1

Hong, J. S., Davis, J. P., Sterzing, P. R., Yoon, J. Choi, S., \& Smith, D. C. (2014). A conceptual framework for understanding the association between school bullying victimization and substance misuse. American Journal of Orthopsychiatry, 84, 696-710. doi:10.1037/ort0000036

Johnston, L. D., O'Malley, P. M., Miech, R. A., Bachman, J. G., \& Schulenberg, J. E. (2015). Monitoring the Future national survey results on drug use, 1975-2014: Overview, key findings on adolescent drug use. Ann Arbor: Institute for Social Research, The University of Michigan. 
This is an author-produced, peer-reviewed version of this article. The final, definitive version of this document can be found online at Journal of Addictions \& Offender Counseling, published by Wiley on behalf of the American Counseling Association. Copyright restrictions may apply. doi: 10.1002/jaoc.12025

Johnston, L. D., O’Malley, P. M., \& Bachman, J. G. (1996). National survey results on drug use from the Monitoring the Future Study, 1975-1995: Vol. 1. Secondary school students (NIH Publication No. 964139). Rockville, MD: National Institute on Drug Abuse.

Juvonen, J., Wang, Y., \& Espinoza, G. (2011). Bullying experiences and compromised academic performance across middle school grades. Journal of Early Adolescence, 31, 152-173. doi:10.1177/0272431610379415

Kelly, E. V., Newton, N. C., Stapinski, L. A., Slade, T., Barrett, E. L., Conrod, P. J., \& Teesson, M. (2015). Concurrent and prospective associations between bullying victimization and substance use among Australian adolescents. Drug and Alcohol Dependence, 154, 63-68. doi:10.1016/j.drugalcdep.2015.06.012

Kenney, S., LaBrie, J., \& Hummer, J. (2010). An examination of prepartying and drinking game playing during high school and their impact on alcohol-related risk upon entrance into college. Journal of Youth and Adolescence, 39, 999-1011. doi:10.1007/s10964-009-9473-1

Klein, J., Cornell, D., \& Konold, T. (2012). Relationships between bullying, school climate, and student risk bheaviors. School Psychology Quarterly, 27, 154-169. doi:http://dx.doi.org/10.1037/a0029350

Klomek, A. B., Marrocco, F., Kleinman, M., Schonfeld, I. S., \& Gould, M. S. (2007). Bullying, depression, and suicidality in adolescents. Journal of the American Academy of Child \& Adolescent Psychiatry, 46, 40-49. doi:10.1097/01.chi.0000242237.84925.18

Lintonen, T., Ahlstrom, S., \& Metso, L. (2004). The reliability of self-reported drinking in adolescence. Alcohol \& Alcoholism, 39, 362-368. doi:10.1093/alcalc/agh071.

Litwiller, B. J., \& Brausch, A. M. (2013). Cyber bullying and physical bullying in adolescent suicide: the role of violent behavior and substance use. Journal of Youth and Adolescence, 42, 675-684. doi:10.1007/s10964013-9925-5

Low, S., \& VanRyzin, M. (2014). The moderating effects of school climate on bullying prevention efforts. School Psychology Quarterly, 29, 306-319. doi:http://dx.doi.org/10.1037/spq0000073

Luk, J. W., Wang, J., \& Simons-Morton, B. G. (2010). Bullying victimization and substance use among U.S. adolescents: Mediation by depression. Prevention Science, 11, 355-359. doi:10.1007/s11121-010-0179-0

MacPherson, H. A., Cheavens, J. S., \& Fristad, M. A. (2013). Dialectical Behavior Therapy for adolescents: Theory, treatment adaptations, and empirical outcomes. Clinical Child and Family Psychology Review, 16, 59-80. doi:0.1007/s10567-012-0126-7

Menard, S., \& Grotpeter, J. K. (2014). Evaluation of bully-proofing your school as an elementary school antibullying intervention. Journal of School Violence, 13, 188-209. doi:10.1080/15388220.2013.840641

Midgett, A., \& Doumas, D. M. (in press). Training elementary students to intervene as peer-advocates to stop bullying at school: A pilot study. Journal of Creativity in Mental Health.

Midgett, A., Doumas, D. M., Sears, D., Lunquist, A., \& Hausheer, R. (2015). A bystander bullying psychoeducation program with middle school students: A preliminary report. The Professional Counselor, 5(4), 486-500. doi:10.15241/am.5.4.486

Miller, J. W., Naimi, T. S., Brewer, R. D., \& Jones, S. E. (2007). Binge drinking and associated health risk behaviors among high school students. Pediatrics, 119, 176-85. doi:http://dx.doi.org/10.1542/peds.2006-1517

Mychailyszyn, M. P., Brodman, D. M., Read, K. L., \& Kendall, P. C. (2012). Cognitive-behavioral school-based interventions for anxious and depressed youth: A meta-analysis of outcomes. Clinical Psychology: Science and Practice, 19, 129-153. doi:10.1111/j.1468-2850.2012.01279.x

Nakamoto, J., \& Schwart, D. (2010). Is peer victimization associated with academic achievement? A meta-analytic review. Social Development, 19, 221-242. doi:10.1111/j.1467-9607.2009.00539.x

Nielsen, M. B., Tangen, T., Idsoe, T., Matthiesen, S. B., \& Mageroy, N. (2015). Post-traumatic stress disorder as a consequence of bullying at work and at school: A literature review and meta-analysis. Aggression and Violent Behavior, 21, 17-24. doi:10.1016/j.avb.2015.01.001

Nguyen-Louie, T. T., Norma Castro, M. S., Matt, G. E., Squeglia, L. M., Brumback, T., \& Tapert, S. F. (2015) Effects of emerging alcohol and marijuana use behaviors on adolescents' neuropsychological functioning over four years. Journal of Studies on Alcohol and Drugs, 76, 738-748. doi:http://dx.doi.org/10.15288/jsad.2015.76.738

Norman, G. R., \& Streiner, D. L. (2008). Biostatistics: The bare essentials (3rd ed.). Hamilton, Ontario: B.C. Decker, Inc.

Peleg-Oren, N., Cardenas, G. A., Comerford, M., \& Galea, S. (2012). An association between bullying behaviors and alcohol use among middle school students. Journal of Early Adolescence, 31, 761-775. doi: $10.1177 / 0272431610387144$ 
This is an author-produced, peer-reviewed version of this article. The final, definitive version of this document can be found online at Journal of Addictions \& Offender Counseling, published by Wiley on behalf of the American Counseling Association. Copyright restrictions may apply. doi: 10.1002/jaoc.12025

Radliff, K., Wheaton, J., Robinson, K., \& Morris, J. (2012). Illuminating the relationship between bullying and substance use among middle and high school youth. Addictive Behaviors, 37, 569-572. doi: 10.1016/j.addbeh.2012.01.001

Rueger, S. Y., \& Jenkins, L. N. (2014). Effects of peer victimization on psychological and academic adjustment in early adolescence. School Psychology Quarterly, 29, 77-88. doi:10.1037/spq000036

Sloboda, Z., Glantz, M. D., \& Tarter, R. E. (2014). Revisiting the concepts of risk and protective factors for understanding the etiology and development of substance use and substance use disorders: Implications for prevention. Substance Use and Misuse, 47, 944-962. doi:10.3109/10826084.2012.663280

Steinberg, L. (2008). A social neuroscience perspective on adolescent risk-taking. Developmental Review, 28, 78106. doi:10.1016/j.dr.2007.08.002

Sullivan, T. N., Farrell, A. D., \& Kliewer, W. (2006). Peer victimization in early adolescence: Association between physical and relational victimization and drug use, aggression, and delinquent behaviors among urban middle school students. Developmental Psychopathology, 18, 119-37. doi: http://dx.doi.org/10.1017/S095457940606007X

Swearer, S. M., Espelage, D. L., Vaillancourt, T., \& Hymel, S. (2010). What can be done about school bullying? Linking research to educational practice. Educational Researcher, 39, 38-47. doi: 10.3102/0013189X09357622.

Tabachnick, B. G., \& Fidell, L. S. (2007). Using multivariate statistics (5th ed.). Boston: Allyn and Bacon.

Tharp-Taylor, S., Haviland, A., \& D’Amico, E.J. (2009). Victimization from mental and physical bullying and substance use in early adolescence. Addictive Behavior, 34, 561-567. doi: 10.1016/j.addbeh.2009.03.012

Thatcher, D. L., \& Clark, D. B. (2008). Adolescents at risk for substance use disorders. Alcohol Research \& Health, 31 (2), 168-176. Retrieved from http://www.mentalhealthacademy.net/journal_archive/niaaa081.pdf

Ttofi, M. M., Farrington, D. P., Losel, F., Crago, R. V., \& Theodorakis, N. (2015). School bullying and drug use later in life: A meta-analytic investigation. School Psychology Quarterly. http://dx.doi.org/10.1037/spq0000120

Ttofi, M. M., Farrington, D. P., Lösel, F., \& Loeber, R. (2011). Do the victims of school bullies tend to become depressed later in life? A systematic review and meta-analysis of longitudinal studies. Journal of Aggression, Conflict and Peace Research, 3, 63-73. doi:10.1108/17596591111132873

Topper, L. R., Castellanos-Ryan, N., Mackie, C., \& Conrod, P. J. (2011). Adolescent bullying victimization and alcohol-related problem behaviour mediated by coping drinking motives over a 12 month period. Addictive Behaviors, 36, 6-13. doi:10.1016/j.addbeh.2010.08.016

U.S. Department of Education (2015). Student reports of bullying and cyber-bullying: Results from the 2031 school crime supplement to the national crime victimization survey. Washington, DC: National Center for Educational. Retrieved from http://nces.ed.gov/pubs2015/2015056.pdf

Valdebenito, S., Ttofi, M., \& Eisner, M. (2015). Prevalence rates of drug use among school bullies and victims: A systematic review and meta-analysis of cross-sectional studies. Aggression and Violence, 23, 137-146.

Volkow, N. D., Baler, R. D., Compton, W. M., \& Weiss, S. R. (2014). Adverse health effects of marijuana use. New England Journal of Medicine, 370, 2219-2227. 
This is an author-produced, peer-reviewed version of this article. The final, definitive version of this document can be found online at Journal of Addictions \& Offender Counseling, published by Wiley on behalf of the American Counseling Association. Copyright restrictions may apply. doi: 10.1002/jaoc.12025

Table 1

Means and Standard Deviations for Substance Use, Victimization, and School Climate by Grade Level

\begin{tabular}{|c|c|c|c|}
\hline Variable & $\begin{array}{l}\text { Middle School } \\
\qquad(n=256)\end{array}$ & $\begin{array}{l}\text { High School } \\
\qquad(n=242)\end{array}$ & $\begin{array}{c}\text { Total } \\
(\mathrm{N}=498)\end{array}$ \\
\hline Alcohol Use & 3.76 (1.69) & $5.80(2.80)$ & $4.76(2.51)$ \\
\hline Tobacco Use & $1.19(.67)$ & $1.75(1.21)$ & 1.47 (1.01) \\
\hline Marijuana Use & $1.21(.54)$ & $2.02(1.34)$ & 1.60 (1.09) \\
\hline Illicit Drug Use & $4.08(.76)$ & $4.58(2.13)$ & 4.32 (1.60) \\
\hline Victimization & $1.16(1.30)$ & $0.40(.87)$ & 0.79 (1.18) \\
\hline School Climate & $5.59(2.46)$ & $7.49(1.82)$ & $6.51(2.37)$ \\
\hline
\end{tabular}


This is an author-produced, peer-reviewed version of this article. The final, definitive version of this document can be found online at Journal of Addictions \& Offender Counseling, published by Wiley on behalf of the American Counseling Association. Copyright restrictions may apply. doi: 10.1002/jaoc.12025

Table 2

Bivariate Correlations for Drinking Variable, Sensation Seeking, and Protective Behavioral Strategies

\begin{tabular}{lllllll}
\hline Measure & 1 & 2 & 3 & 4 & 5 & 6 \\
\hline
\end{tabular}

Middle School $(n=256)$
1. Alcohol Use
2. Tobacco Use
3. Marijuana Use
4. Illicit Drug Use
5. Victimization
6. School Climate

$\begin{array}{lllll}- & - & & & \\ .45^{* *} & .53^{* *} & - & & \\ .46^{* *} & .23^{* *} & .36^{* *} & - & \\ .40^{* *} & .02 & .15^{*} & .18^{* *} & - \\ .17^{*} & -.13 & -.15^{*} & -.11 & -.32^{* *} \\ -.20^{* *} & & & -\end{array}$

High School $(n=242)$
1. Alcohol Use
2. Tobacco Use
3. Marijuana Use
4. Illicit Drug Use
5. Victimization
6. School Climate

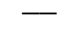

$\begin{array}{ll}.46^{* *} & - \\ .60^{* *} & .60^{* *} \\ .44^{* *} & .35^{* *} \\ .11 & .22 * * \\ .12 & -.15^{*}\end{array}$

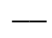

$.38 * *$

$.20 * * \quad .43 * *$

$\begin{array}{lll}-.14 * & -.24 * * & -.27 * *\end{array}$
$-.14$ 
This is an author-produced, peer-reviewed version of this article. The final, definitive version of this document can be found online at Journal of Addictions \& Offender Counseling, published by Wiley on behalf of the American Counseling Association. Copyright restrictions may apply. doi: 10.1002/jaoc.12025

Table 3

Summary of Hierarchical Regression Analysis

Outcome Variable

$\begin{array}{lll}\text { Alcohol Tobacco } & \text { Marijuana }\end{array}$

\begin{tabular}{|c|c|c|c|c|c|c|c|c|c|c|c|c|c|}
\hline Step & Predictor & $\Delta \mathrm{R}^{2}$ & $\beta$ & $r_{p}$ & $\Delta \mathrm{R}^{2}$ & $\beta$ & $\mathrm{r}_{\mathrm{p}}$ & $\Delta \mathrm{R}^{2}$ & $\beta$ & $\mathrm{r}_{\mathrm{p}}$ & $\Delta \mathrm{R}^{2}$ & $\beta$ & $\mathrm{r}_{\mathrm{p}}$ \\
\hline \multirow[t]{4}{*}{1} & & $.18^{* * *}$ & & & $.09 * * *$ & & & $.16^{* * *}$ & & & $.09 * * *$ & & \\
\hline & Victimization & & .09 & .08 & & .09 & .08 & & $.13 * *$ & .11 & & $.25 * * *$ & .22 \\
\hline & Grade Level & & $.48 * * *$ & .43 & & $.35 * * *$ & .32 & & $.44 * * *$ & .39 & & $.25 * * *$ & .23 \\
\hline & School Climate & & $-.12 *$ & -.10 & & $-.11 *$ & -.09 & & -.08 & -.07 & & -.09 & -.08 \\
\hline \multirow[t]{7}{*}{2} & & .00 & & & $.02 * *$ & & & $.02 * *$ & & & $.08 * *$ & & \\
\hline & Victimization & & $.10^{*}$ & .08 & & $.16^{* *}$ & .12 & & $.19 * * *$ & .15 & & $.36 * * *$ & .29 \\
\hline & Grade Level & & $.48^{* * *}$ & .42 & & $.36^{* * *}$ & .32 & & $.45^{* * *}$ & .40 & & $.31^{* * *}$ & .27 \\
\hline & School Climate & & $-.12 *$ & -.10 & & $-.11 *$ & -.09 & & -.09 & -.08 & & -.10 & -.08 \\
\hline & $\mathrm{V} \times \mathrm{L}$ & & .03 & .03 & & $.17^{* * *}$ & .14 & & $.12 *$ & .10 & & $.28 * * *$ & .24 \\
\hline & $\mathrm{V} \times \mathrm{C}$ & & .01 & .01 & & -.02 & -.02 & & .05 & .04 & & $.12 *$ & .09 \\
\hline & $V \times L \times C$ & & .01 & .00 & & -.02 & -.02 & & -.00 & -.00 & & $.13^{*}$ & .09 \\
\hline
\end{tabular}

Note. $\Delta \mathrm{R}^{2}=\mathrm{R}^{2}$ change; $\beta=$ standardized regression coefficient; $\mathrm{r}_{\mathrm{p}}=$ semi-partial correlation coefficient; V $\mathrm{x} \mathrm{L}=\mathrm{Victim} \mathrm{x}$ Level; $\mathrm{V} \mathrm{x} \mathrm{C}=\mathrm{Victim} \mathrm{x}$ Climate; $\mathrm{V} \mathrm{x}$ L x C = Victim x Level x Climate

$* p<.05, * * p<.01, * * * p<.001$. 

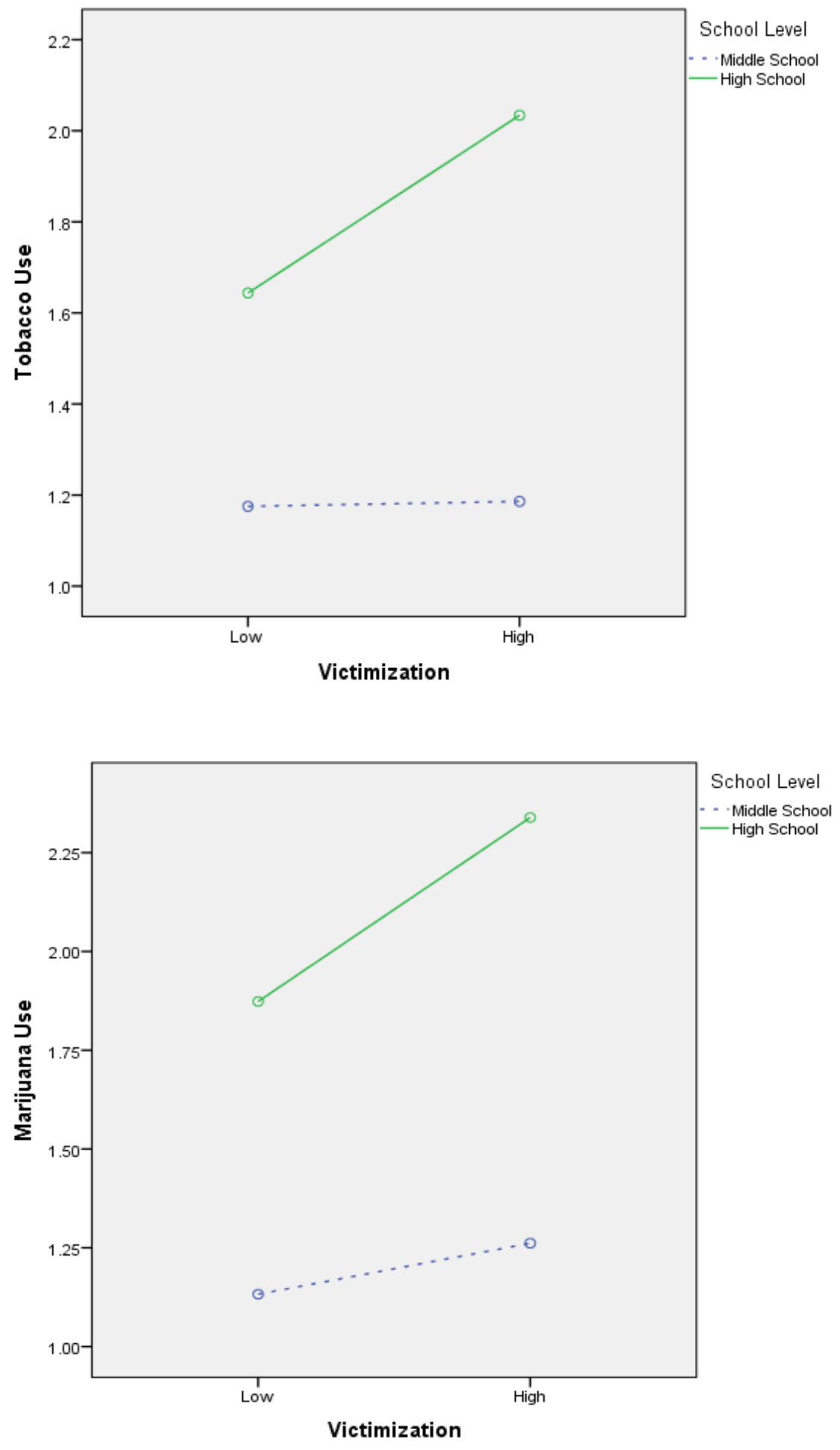

Figure 1. Relationship Between Victimization and Substance Use for High School Students 
This is an author-produced, peer-reviewed version of this article. The final, definitive version of this document can be found online at Journal of Addictions \& Offender Counseling, published by Wiley on behalf of the American Counseling Association. Copyright restrictions may apply. doi: 10.1002/jaoc.12025

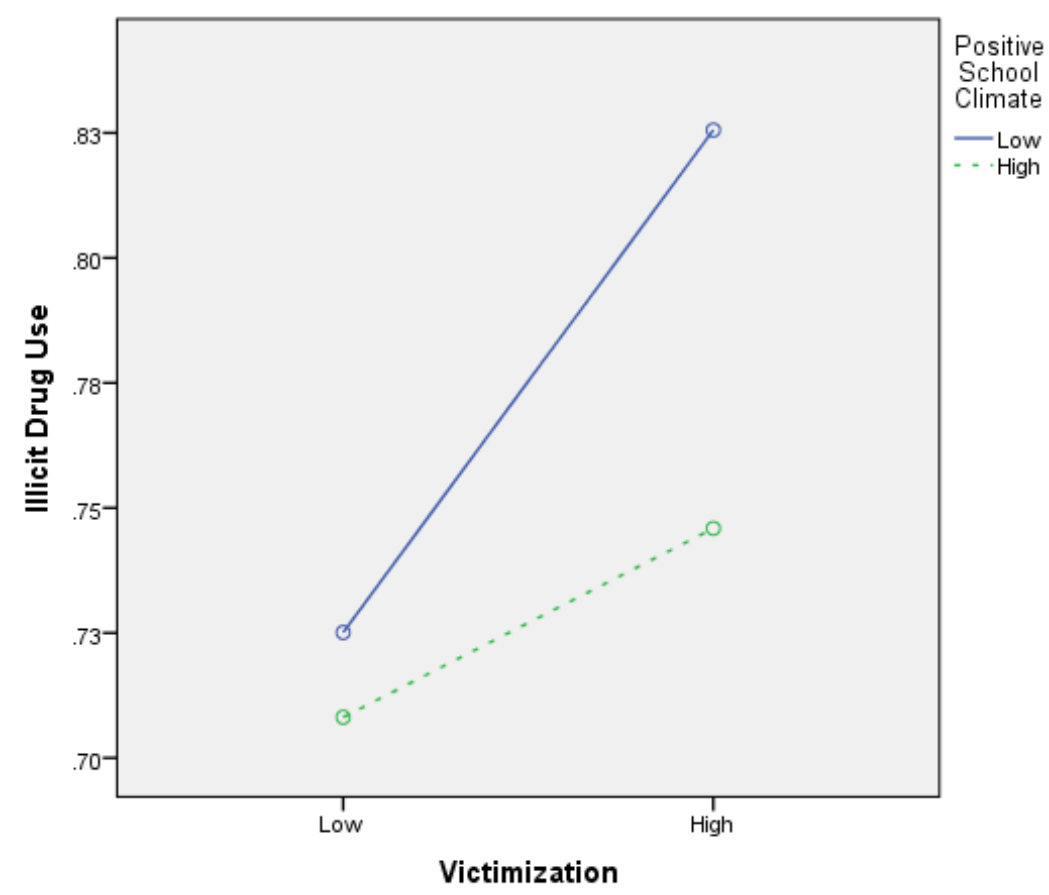

Figure 2. Relationship Between Victimization and Illicit Drug Use Moderated by School Climate for High School Students 